\author{
National Headquarters \\ SELECTIVE SERVICE SYSTEM \\ 21st Street and C Street, N. W. \\ Washington, D. C.
}

COPY

June 18, 1942

\title{
OCCUPATIONAL BULLETIN (NO. 10)
}

Subject: Scientific and Specialized Personnel

EFFECTIVE: IMMEDIATELY

Distribution: State Directors

BoARd of Appeal Members

Local Board Members

Government Appeal Agents

\section{PART I}

1. There are certain persons trained, qualified, or skilled in scientific and specialized fields who, if engaged in the practice of their respective professions, are in a position to perform a vital service in activities necessary to war production and in activities essential to the support of the war effort.

\section{PART II}

1. The National Roster of Scientific and Specialized Personnel has certified to the Director of Selective Service that in activities necessary to war production and in activities essential to the support of the war effort, there are certain "critical occupations" which for the proper discharge of the duties involved require a high degree of training, qualification, or skill in scientific and specialized fields. The critical occupations in these scientific and specialized fields, as certified to the Director of Selective Service, are listed on page 4 attached to this bulletin.

2. All of these critical occupations, as listed, require highly specialized periods of training of two years or more. The critical occupations on the attached list exist within the provisions of Part V, Memorandum to All State Directors (I-405).

\section{PART III}

1. The National Roster of Scientific and Specialized Personnel has certified to the Director of Selective Service that there are serious shortages of persons trained, qualified, or skilled to engage in these critical occupations in activities necessary to war production and in activities essential to the support of the war effort. These shortages exist within the provisions of Part VII, Memorandum to All State Directors (I-405), and accordingly careful consideration for occupational classification should be given to all persons trained, qualified, or skilled in these critical occupations and who are engaged in activities necessary to war production or essential to the support of the war effort.

\section{PART IV}

1. There are many registrants who are in training and preparation to acquire the qualification or skill to engaged in these critical occupations. Normally the period of training and preparation to acquire the necessary qualification or skill in these scientific and specialized fields extends over a period of four academic years in a recognized academic, professional, or technical college or university. In many instances, however, 
it is necessary for persons to have additional study in a recognized academic, professional, or technical college or university in order to acquire the more highly specialized qualification or skill necessary for the performance of particular services in activities necessary to war production or essential to the support of the war effort. Persons engaging in further studies in addition to the four academic years normally required are referred to as graduate or postgraduate students.

2. A registrant who is in training and preparation for one of these scientific and specialized fields may not be considered for occupational classification until the close, or approximately the close, of his second or sophomore year in a recognized college or university.

3. A registrant who is in training and preparation for one of these scientific and specialized fields may be considered for occupational deferment at the close, or approximately at the close, of his second or sophomore year in a recognized college or university if he is pursuing a course of study upon the successful completion of which he will have acquired the necessary training, qualification, or skill, and if he gives promise of continuing and will be acceptable for continuing such course of study and will undertake actual further classroom work within a period of not to exceed four months from the close of his second year.

4. A registrant who is in training and preparation for one of these scientific and specialized fields shall be considered for occupational classification during his third and fourth years in a recognized college or university, provided that he gives promise of the successful completion of such course of study and the acquiring of the necessary degree of training, qualification, or skill.

5. A graduate or postgraduate student who is undertaking further studies for these scientific and specialized fields, following the completion of the normal four academic years, may be considered for occupational classification if, in addition to pursuing the additional studies, he is also acting as "graduate assistant" in a recognized college or university or is engaged in scientific research related to the war effort and which is supervised by a recognized Federal agency. A graduate assistant is a student in postgraduate studies who, in addition, is engaged in the teaching and instruction of undergraduate students in these scientific and specialized fields.

6. When a registrant has completed his training and preparation in a recognized college or university and has acquired a high degree of training, qualification, or skill in one of these scientific and specialized fields, such registrant should then be given the opportunity to become engaged in the practice of his profession in an activity necessary to war production or essential to the support of the war effort. In many instances following graduation from a recognized college or university, a certain period of time will be required in the placing of trained, qualified, or skilled personnel in an essential activity. When a registrant has been deferred as a necessary man in order to complete his training and preparation, it is only logical that his deferment should continue until he has an opportunity to use his scientific and specialized training to the best interest of the nation. Accordingly, following graduation from a recognized college or university in any of these scientific and specialized fields, a registrant should be considered for further occupational classification for a period of not to exceed 60 days in order that he may have an opportunity to engage in a critical occupation in an activity necessary to war production or essential to the support of the war effort, provided that during such period the registrant is making an honest and diligent effort to become so engaged.

Lewis B. Hershey, Director 


\section{CRITICAL OCCUPATIONS}

Scientific and Specialized Personnel

Accountants

Chemists

Economists

Engineers:

Aeronautical Engineers

Automotive Engineers

Chemical Engineers

Civil Engineers

Electrical Engineers

Heating, Ventilating, Refrigerating, and Air Conditioning Engineers

Marine Engineers

Mechanical Engineers

Mining and Metallurgical Engineers, including Mineral Technologists

Radio Engineers

Safety Engineers

Transportation Engineers-Air, Highway, Railroad, Water

Geophysicists

Industrial Managers

Mathematicians

Meteorologists

Naval Architects

Personnel Administrators

Physicists, including Astronomers

Psychologists

Statisticians 